\title{
Role of Some Antibacterial Drugs in Control Streptococcus iniae Infection in Oreochromis niloticus
}

\author{
Ibrahim Mohamed Aboyadak ${ }^{1 *}$, Nadia Gabr Ali ${ }^{1}$, Moustafa Abdel-Aziz Mohamed ${ }^{2}$, Mohamed Saied Gado ${ }^{3}$ and \\ Kamal Ahmed El-Shazly² \\ ${ }^{1}$ Fish disease lab, Notational Institute of Oceanography and Fishery (NIOF), Egypt
}

${ }^{2}$ Department of Pharmacology, Faculty of Veterinary Medicine, Kafrelsheikh University, Egypt

${ }^{3}$ Department of fish diseases and management, Faculty of Veterinary Medicine, Kafrelsheikh University, Egypt

Submission: November 08, 2016; Published: November 30, 2016

*Corresponding author: Ibrahim Mohammed Aboyadak, Fish disease lab, Notational Institute of Oceanography and Fishery (NIOF), Alexandria branch, Egypt

\begin{abstract}
Streptococcus iniae infection is considered one of the most important diseases affecting cultured fish causing severe economic losses. This work was conducted to determine the efficacy of some antibacterial drugs in treatment of Nile tilapia (Oreochromis niloticus) fish experimentally infected by Streptococcus iniae which were done through; determine the sensitivity of Streptococcus iniae to different antibiotics, detect the lethal dose fifty $\left(\mathrm{LD}_{50}\right)$ of tested Streptococcus iniae strain in Oreochromis niloticus followed by treatment of the experimentally infected fish with florfenicol, norfloxacin and oxytetracycline at a dose of 50,100 and $100 \mathrm{mg} / \mathrm{kg}$ body weight respectively by oral gavage. AST, ALT, uric acid and creatinine in fish serum was studied together with histopathological examination of liver and posterior kidney tissues.

Tested Streptococcus iniae strain was sensitive to Florfenicol, Norfloxacin and Oxytetracycline with MIC equal to $8,0.25 \mathrm{and} 2 \mu \mathrm{g} / \mathrm{ml}$ respectively. The $\mathrm{LD}_{50}$ of Streptococcus iniae in Oreochromis niloticus weighting $80 \pm 5 \mathrm{~g}$ was $0.2 \mathrm{ml}$ of $\left(6 \times 10^{8}\right) \mathrm{CFU} / \mathrm{ml}$ by intraperitoneal inoculation. There were no mortalities in infected florfenicol and norfloxacin treated groups while it was $20 \%$ in infected oxytetracycline treated group. Florfenicol, norfloxacin and oxytetracycline can be considered an effective treatment for control of susceptible Streptococcus iniae infection in Oreochromis niloticus at a dose level of 50,100 and $100 \mathrm{mg} / \mathrm{kg}$ body weight respectively for seven successive days.
\end{abstract}

Keywords: Streptococcus iniae; Oreochromis niloticus; Florfenicol; Norfloxacin; Oxytetracycline; LD $_{50}$; AST; ALT; Uric acid; Creatinine Hepatopancreas; Posterior kidney; Histopathology

Abbreviations: NIOF: National Institute of Oceanography and Fisheries; LD $_{50}$ : Lethal Dose; ALT: Alanine Aminotransferase; AST: Aspartate Aminotransferase

\section{Introduction}

According to FAO, tilapias (Oreochromis sp.) are among the most cultured fish worldwide as it rose commercially in more than 100 countries [1]. Egypt is producing about $71.38 \%$ of total cultured fish in Africa and occupies the eighth level all over the world as it is producing about 919585 tons of cultured fish that represents $1.54 \%$ of total cultured fish all over the world according to [2] report. Streptococcal infection in fish is a septicemic disease that has been reported worldwide causing severe economic losses in fish production [3]. It has been reported in many other fish species throughout the world, contributing to an annual loss of approximately 250 million USD annually in 2008 [4]. Streptococcus iniae is an encapsulated,
non-Lancefield group, beta-hemolytic, gram-positive cocci [5]. Streptococcus iniae produces a cytolysin with haemolytic traits, which is a functional homologue of streptolysin S. Expression of this cytolysin is necessary for local tissue necrosis [6].

Increased AST and ALT as a result of hepatic cells destruction together with increased creatinine due to posterior kidney destruction in infected fish was recorded by [7]. Presence of degenerative changes in liver and posterior kidney tissues of experimentally infected Oreochromis niloticus was recorded by [8]. Antibiotics are very useful tool to any fish-health manager's to help in elimination of bacterial fish diseases [9]. Oxytetracycline was found to be the antibiotic having the highest 
frequency of application in aquaculture, while the second most widely used antibiotic was florfenicol followed by norfloxacin [10]. The aim of the present work is to determine the efficacy of Florfenicol, Norfloxacin and Oxytetracycline in treatment of Nile tilapia (Oreochromis niloticus) experimentally infected by Streptococcus iniae from the survival percent, together with detects improvement of liver and posterior kidney organ function can result by termination of infection.

\section{Materials and methods}

\section{Drugs}

Floricol $^{\circledR} 10 \%$ florfenicol oral solution and Oxyvet ${ }^{\circledR} 20 \%$ Oxytetracycline $\mathrm{Hcl}$ water soluble powder from Pharma Swede co, Egypt. Epinor ${ }^{\circledR} 400 \mathrm{mg}$ Norfloxacin tablets EIPICO, Egypt were used.

\section{Fish diet}

Fish were fed on commercial extruded pellet ration containing $35 \%$ total protein. Feeding was performed once daily as $3 \%$ of fish body weight according to [11].

\section{Bacterial strain}

A virulent strain of Streptococcus iniae was obtained kindly from the fish disease lab, National Institute of Oceanography and Fisheries (NIOF), Alexandria branch, Egypt.

\section{Bacteriological Media}

Tryptic Soy broth, Tryptic Soy agar, Muller - Hinton broth and Muller - Hinton agar manufactured by Oxoid, U. K were used in growth and sensitivity tests for Streptococcus iniae.

\section{Sensitivity discs}

Sensitivity discs of florfenicol, norfloxacin and oxytetracycline, (Bioanalyse) $\AA^{\circledR}$, Turkey are used.

\section{Anesthetic}

Quinaldine (Argent), USA was used as a fish anesthetic during all experiments at a dose of $25 \mathrm{mg} / \mathrm{l}$ as described by [12].

\section{Kits}

Kits for determination of ALT, AST, creatinine and uric acid were manufactured by Bio Diagnostic, Egypt.

\section{Antimicrobial sensitivity tests}

Agar disc diffusion test was performed as described by [13] and broth micro dilution test was performed as described by [14].

\section{Experimental design}

I. Experimental animals: A total number of 110 apparently healthy Nile tilapia (Oreochromis niloticus) weighing $80 \pm 5 \mathrm{~g}$ were used. They were maintained 15 days prior to the experimental infection for acclimatization according to [15]. Fish were mentioned in 400 litter fiberglass tank supplied with dechlorinated tape water, with continues aeration, $20 \%$ water change was done each other day.

II. Pathogenicity test: Sixty apparently healthy Nile tilapia (Oreochromis niloticus) fish weighting $80 \pm 5 \mathrm{~g}$ were used in the pathogenicity test to determine the median lethal dose $\left(\mathrm{LD}_{50}\right)$ of Streptococcus iniae according to method described by [16]. Six equal groups each contain 10 fish, the first group (control) injected intraperitoneal with $0.2 \mathrm{ml}$ of sterile (PBS), the second group injected intraperitoneal with $0.2 \mathrm{ml}$ of Streptococcus iniae contain $6 \times 10^{8} \mathrm{CFU} / \mathrm{ml}$ sterile (PBS), and each following group inoculated with 10 fold serial dilution. Each group were maintained in 100 litter glass aquarium supplied with dechlorinated tape water, with continues aeration, $20 \%$ water change was done each other day.

III. Determination of in vivo efficacy of antibiotics in treatment of experimentally infected fish with Streptococcus iniae: Fifty apparent healthy Oreochromis niloticus fish weighting $80 \pm 5 \mathrm{~g}$ were grouped into 5 groups 10 fish in each group. Group 1 was negative control inoculated with $0.2 \mathrm{ml}$ each fish with sterile (PBS) by intraperitoneal injection and group 2, 3, 4 and 5 were inoculated with $0.2 \mathrm{ml}$ PBS containing $\left(6 \times 10^{8}\right) \mathrm{CFU}\left(\mathrm{LD}_{50}\right)$ for induction of experimental infection. Drugs were administrated 24 hours post experimental infection by oral gavage daily for 7 days as shown in (Tables 1).

Table 1: Used drug doses and duration of treatment.

\begin{tabular}{|c|c|}
\hline Group & Treatment \\
\hline $\begin{array}{c}\text { Group 1: Non-infected Non- } \\
\text { treated }\end{array}$ & - \\
\hline Group 2: Infected non-treated & - \\
\hline $\begin{array}{c}\text { Group 3: Infected Florfenicol } \\
\text { treated }\end{array}$ & $\begin{array}{c}\text { Florfenicol } 50 \mathrm{mg} / \mathrm{kg} \text { B.W. once } \\
\text { daily by gavage for } 7 \text { days }\end{array}$ \\
\hline $\begin{array}{c}\text { Group 4: Infected Norfloxacin } \\
\text { treated }\end{array}$ & $\begin{array}{c}\text { Norfloxacin } 100 \mathrm{mg} / \mathrm{kg} \text { B.W. once } \\
\text { daily by gavage for } 7 \text { days }\end{array}$ \\
\hline $\begin{array}{c}\text { Group 5: Infected Oxytetracycline } \\
\text { treated) }\end{array}$ & $\begin{array}{l}\text { Oxytetracycline } 100 \mathrm{mg} / \mathrm{kg} \mathrm{B.W} \text {. } \\
\text { once daily by gavage for } 7 \text { days }\end{array}$ \\
\hline
\end{tabular}

IV. Blood samples: Blood was collected via heart puncture according to the method described by [17]. Samples were collected from each group one day after end of treatment. Serum was separated by centrifugation at $3000 \mathrm{rpm}$ for 5 min and kept at $-20^{\circ} \mathrm{C}$ for biochemical analysis.

V. Serum biochemical analysis: The activity of serum alanine aminotransferase (ALT) and serum aspartate aminotransferase (AST) was determined according to [18]. Serum creatinine was determined according to the method described by [19] and Serum uric acid was determined according to the method described by [20].

VI. Histopathological examination: Hepatopancreas (liver) and posterior kidney tissue specimens were taken 
from all groups one day after end of treatment then were immediately fixed in $10 \%$ neutral buffered formalin, and then dehydrated, in ascending grades ethyl alcohol. Samples were cleared in three changes of xylol, and then

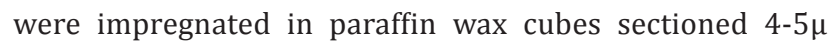
thickness. Sections were mounted on slides and stained with haematoxylin and eosin according to the method described by [21].

VII. Statistical analysis: The data were statistically analyzed for variance (ANOVA) and least significant difference as described by [22] using (SPSS version 16) computer statistical software. Data were evaluated as significant at $\mathrm{P} \leq 0.05$.

\section{Results}

Agar disc diffusion test and broth micro dilution test revealed sensitivity of Streptococcus iniae to florfenicol, norfloxacin and oxytetracycline with MIC equal to $8,0.25$ and $2 \mu \mathrm{g} / \mathrm{ml}$ respectively (Table 2). Pathogenicity test revealed that the $\mathrm{LD}_{50}$ of Streptococcus iniae in Oreochromis niloticus fish weighting $80 \pm 5 \mathrm{~g}$ was $0.2 \mathrm{ml}$ of $\left(6 \times 10^{8}\right) \mathrm{CFU} / \mathrm{ml}$ by intraperitoneal inoculation (Table 3 ) and (Figure 1). The mortality rate at the end of experiment was shown in (Table 4) and (Figure 2) in which infected florfenicol and infected norfloxacin treated groups showed no mortalities while oxytetracycline group showed 20\% mortality. Serum biochemical analysis of liver function tests in (Table 5) and (Figures 3 \& 4) and kidney functions tests results were shown in (Table 6) and (Figures 5 \& 6). The histopathological examination of hepatopancreas of different groups was shown in (Figures 7A -7E) and that of posterior kidney tissue shown in (Figures 8A -8E).

Table 2: Antimicrobial sensitivity and Broth micro dilution tests results.

\begin{tabular}{|c|c|c|c|}
\hline Antibiotic & $\begin{array}{c}\text { Disc } \\
\text { concentration } \\
(\boldsymbol{\mu g} / \mathbf{d i s c})\end{array}$ & $\begin{array}{c}\text { Inhibition } \\
\text { Zone diameter } \\
\mathbf{m m}\end{array}$ & MIC $(\boldsymbol{\mu g} / \mathbf{m l})$ \\
\hline Norfloxacin & NOR (10) & 22.15 & 0.25 \\
\hline Florfenicol & KF (10) & 22.55 & 8 \\
\hline Oxytetracycline & OT (30) & 19.35 & 2 \\
\hline
\end{tabular}

Table 3: Pathogenicity test result.

\begin{tabular}{|c|c|c|}
\hline Group & Inoculums & Mortality \% \\
\hline Group (1) & $0.2 \mathrm{ml}$ of sterile PBS. & $0 \%$ \\
\hline Group (2) & $\begin{array}{c}0.2 \mathrm{ml} \text { of }\left(6 \times 10^{8}\right) \\
\mathrm{CFU} / \mathrm{ml}\end{array}$ & $50 \%$ \\
\hline Group (3) & $\begin{array}{c}0.2 \mathrm{ml} \mathrm{of}\left(6 \times 10^{7}\right) \\
\mathrm{CFU} / \mathrm{ml}\end{array}$ & $20 \%$ \\
\hline Group (4) & $\begin{array}{c}0.2 \mathrm{ml} \mathrm{of}\left(6 \times 10^{6}\right) \\
\mathrm{CFU} / \mathrm{ml}\end{array}$ & $0 \%$ \\
\hline Group (5) & $\begin{array}{c}0.2 \mathrm{ml} \mathrm{of}\left(6 \times 10^{5}\right) \\
\mathrm{CFU} / \mathrm{ml}\end{array}$ & $0 \%$ \\
\hline Group (6) & $\begin{array}{c}0.2 \mathrm{ml} \mathrm{of}\left(6 \times 10^{4}\right) \\
\mathrm{CFU} / \mathrm{ml}\end{array}$ \\
\hline
\end{tabular}

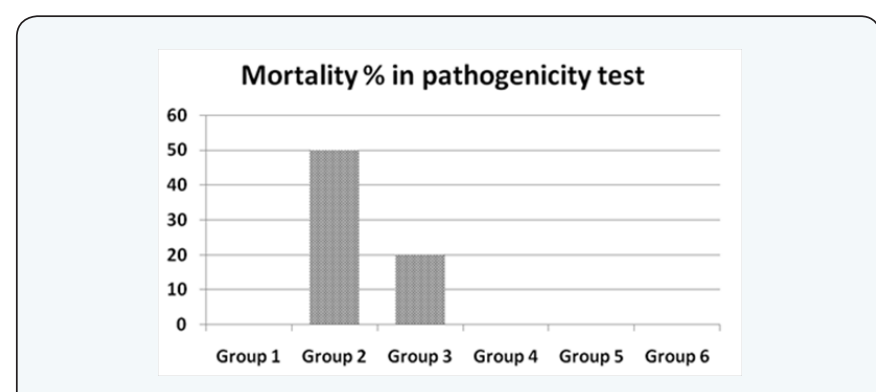

Figure 1: $\mathrm{LD}_{50}$ of Streptococcus innae to Oreochromis nilocticus.

Table 4: The mortalities rate at the end of treatment.

\begin{tabular}{|c|c|c|}
\hline Group & Treatment & Mortality \% \\
\hline Group (1) & $\begin{array}{c}\text { Non-infected non- } \\
\text { treated }\end{array}$ & $0 \%$ \\
\hline Group (2) & $\begin{array}{c}\text { Infected non-treated } \\
\text { Group (3) }\end{array}$ & $\begin{array}{c}\text { Infected florfenicol } \\
\text { treated }\end{array}$ \\
\hline Group (4) & $\begin{array}{c}\text { Infected norfloxacin } \\
\text { treated }\end{array}$ & $0 \%$ \\
\hline Group (5) & $\begin{array}{c}\text { Infected } \\
\text { oxytetracycline } \\
\text { treated }\end{array}$ & $20 \%$ \\
\hline
\end{tabular}

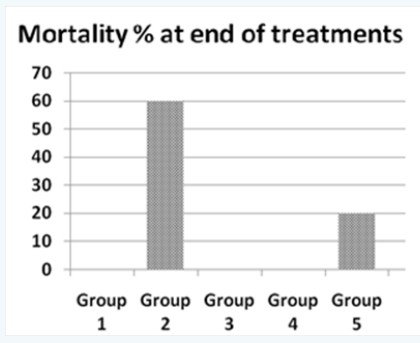

Figure 2: Mortality rate at end of treatment trial.

Table 5: Serum ALT and AST level of different groups.

\begin{tabular}{|c|c|c|c|}
\hline Group & ALT U/L & AST U/L & No. of samples \\
\hline Group (1) & $39 \pm 2.19^{\mathrm{b}}$ & $141.12 \pm 5.09^{\mathrm{b}}$ & 8 \\
\hline Group (2) & $55 \pm 2.58^{\mathrm{a}}$ & $172.33 \pm 4.77^{\mathrm{a}}$ & 6 \\
\hline Group (3) & $46.42 \pm 2.04^{\mathrm{bc}}$ & $154.57 \pm 5.82^{\mathrm{bc}}$ & 7 \\
\hline Group (4) & $45.37 \pm 3.12^{\mathrm{bc}}$ & $149 \pm 5.23^{\mathrm{b}}$ & 8 \\
\hline Group (5) & $51.83 \pm 3.21^{\mathrm{ac}}$ & $167 \pm 5.68^{\mathrm{ac}}$ & 6 \\
\hline
\end{tabular}

Values are mean \pm S.E. data were compared by ANOVA, values at the same column and has the same letter are non-significant at $P \leq 0.05$. 


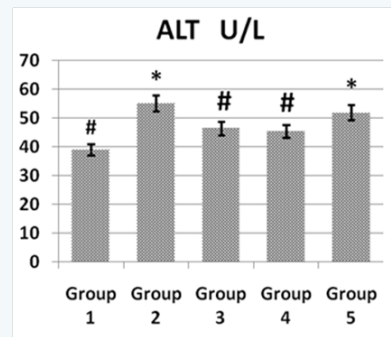

Figure 3: Serum alanine aminotransferase (ALT) level.

*Significant change with Non-infected non-treated group.

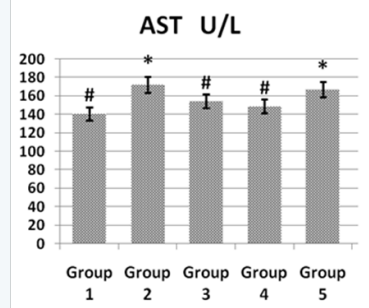

Figure 4: Serum aspartate aminotranferase (AST) level. \#Significant change with infected non-treated group.

Table 6: Serum creatinine and uric acid level of different groups.

\begin{tabular}{|c|c|c|c|}
\hline Group & $\begin{array}{c}\text { Creatinine } \\
\mathbf{m g} / \mathbf{d l}\end{array}$ & $\begin{array}{c}\text { Uric acid mg/ } \\
\mathbf{d l}\end{array}$ & No. of samples \\
\hline Group (1) & $0.22 \pm 0.015^{\mathrm{b}}$ & $1.65 \pm 0.079^{\mathrm{b}}$ & 8 \\
\hline Group (2) & $0.35 \pm 0.012^{\mathrm{a}}$ & $2.27 \pm 0.083^{\mathrm{a}}$ & 6 \\
\hline Group (3) & $0.28 \pm 0.020^{\mathrm{bc}}$ & $1.83 \pm 0.053^{\mathrm{bc}}$ & 7 \\
\hline Group (4) & $0.26 \pm 0.025^{\mathrm{bc}}$ & $1.77 \pm 0.096^{\mathrm{bc}}$ & 8 \\
\hline Group (5) & $0.31 \pm 0.022^{\mathrm{ac}}$ & $1.98 \pm 0.183^{\mathrm{bc}}$ & 6 \\
\hline
\end{tabular}

Values are mean \pm S.E. data were compared by ANOVA, values at the same column and has the same letter are non-significant at $P \leq 0.05$.

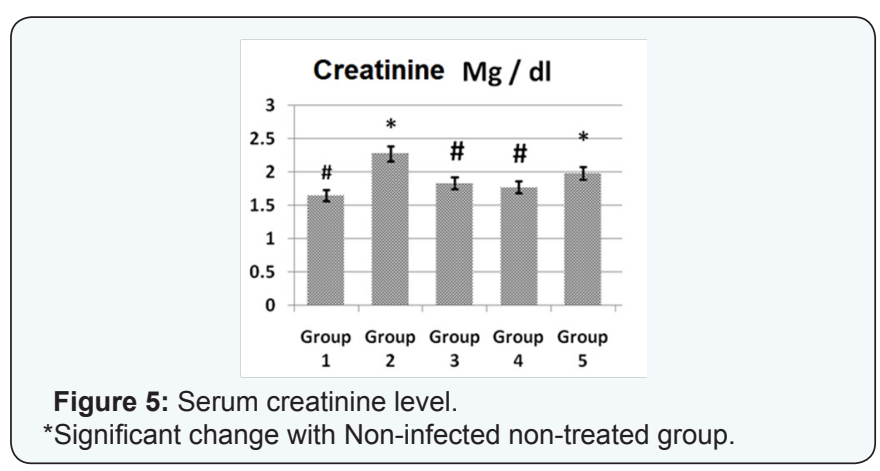

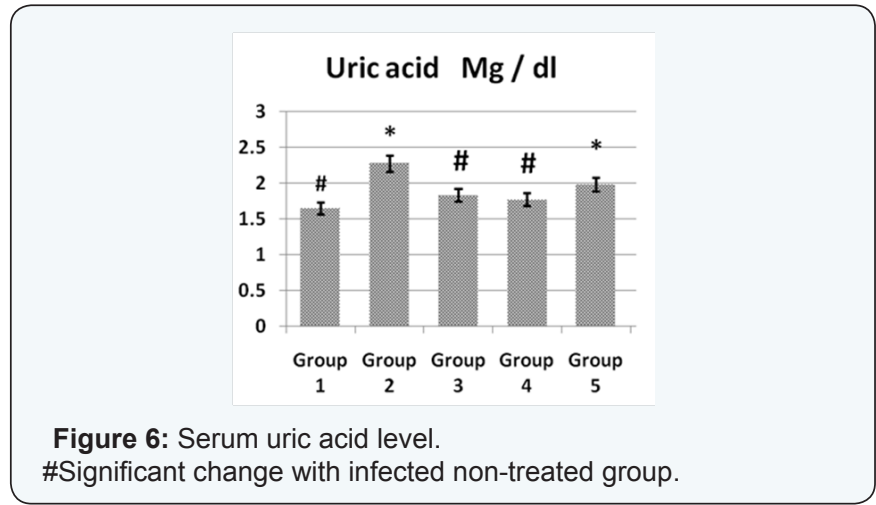

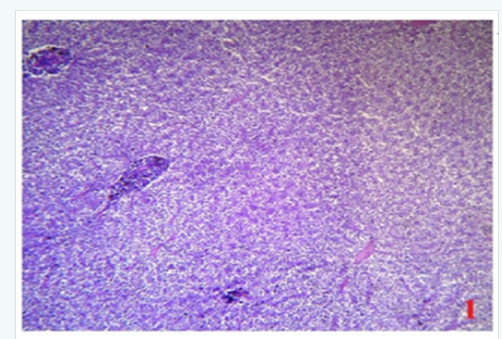

Figure 7(A): Hepatopancreas of normal fish showing normal tissue architecture, normal hepatocytes with absence of inflammatory reaction and normal blood sinusoids $(X=200)$.

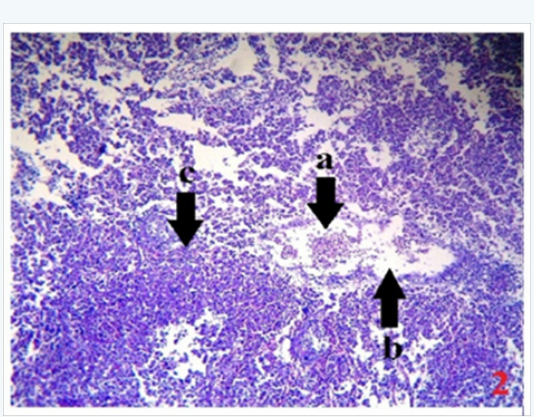

Figure 7(B): Hepatopancreas of infected non treated fish showing haemorrhage (a), necrosis (b) and mononuclear cell infiltration (c). $(X=200)$.

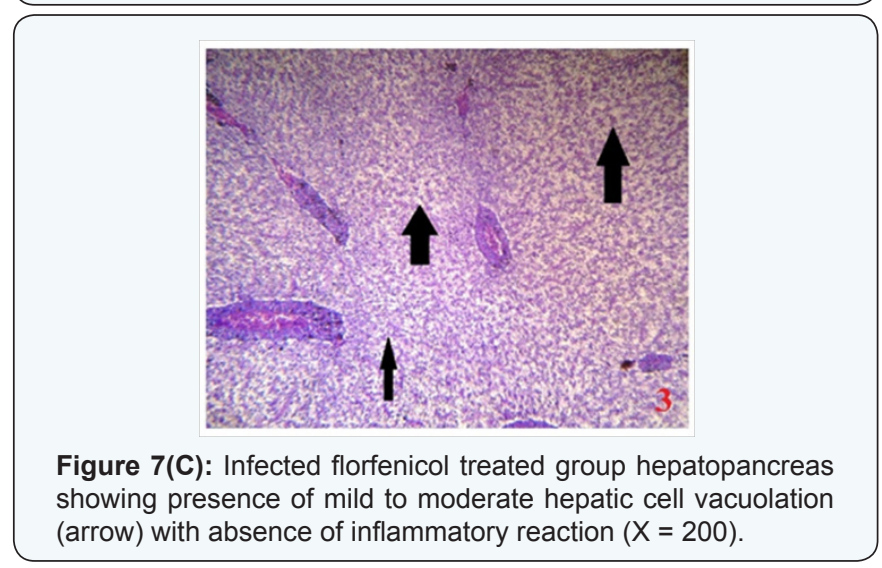




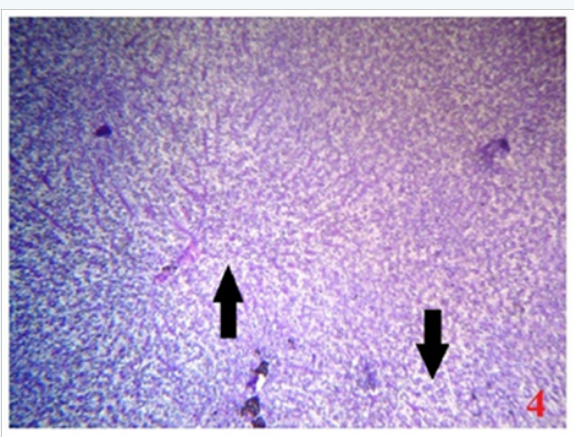

Figure 7(D): Infected norfloxacin treated group hepatopancreas showing presence of mild hepatic cell vacuolation (arrow) with absence of inflammatory reaction $(X=200)$.

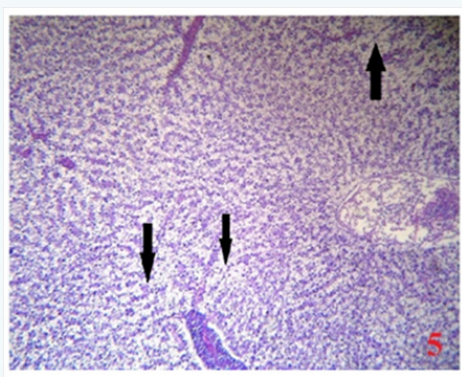

Figure 7(E): Infected oxytetracycline treated group hepatopancreas showing presence of moderate to severe hepatic cell vacuolation (arrow) with absence of inflammatory reaction. $(X=200)$.

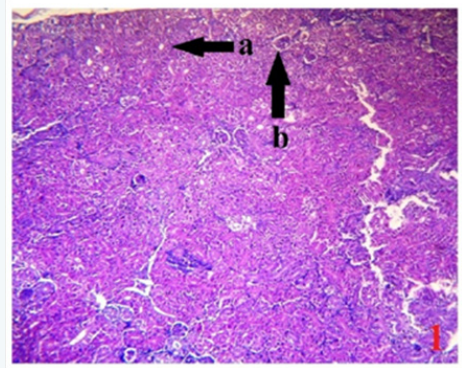

Figure 8(A): Posterior kidney of normal fish showing normal tissue architecture, normal convoluted tubules (a) normal glomeruli and Bowman's space (b) absence of inflammatory reaction or congestion $(X=200)$.

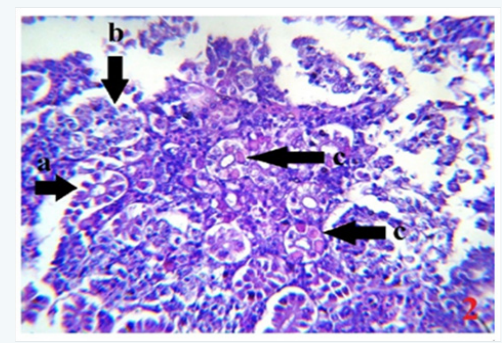

Figure 8(B): Posterior kidney of infected non treated fish showing degenerated renal tubules showing sloughing of tubular epithelium (a), degeneration of glomerular tuft with presence of hyaline droplet degeneration (c) of tubular epithelium $(X=800)$.

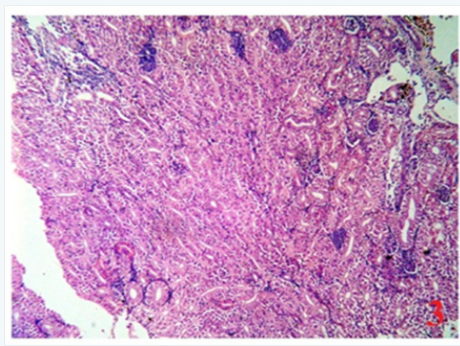

Figure 8(C): Infected florfenicol treated group posterior kidney showing normal tissue architecture, normal convoluted tubules, normal glomeruli and Bowman's space with absence of inflammatory reaction or congestion $(X=200)$.

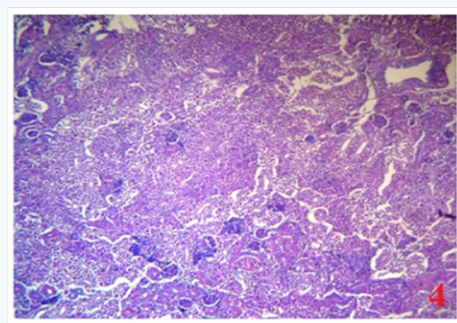

Figure 8(D): Infected norfloxacin treated group posterior kidney showing normal tissue architecture, normal convoluted tubules, normal glomeruli and Bowman's space with absence of inflammatory reaction or congestion $(X=200)$.

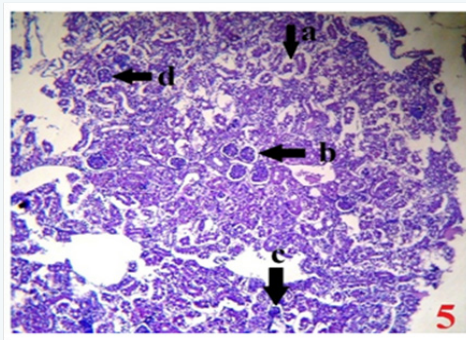

Figure 8(E): Infected oxytetracycline treated group posterior kidney showing presence of degeneration and detachment of tubular epithelium of some renal tubules (a), increase of Bowman's space (b), some glomeruli shows degeneration (c) and other showing hypertrophy $(\mathrm{d})$ with absence of inflammatory reaction $(X=200)$.

\section{Discussion}

It was evident from the present work that $\mathrm{LD}_{50}$ of Streptococcus iniae in Oreochromis niloticus was $0.2 \mathrm{ml}$ of $6 \times$ $10^{8} \mathrm{CFU}$ by intraperitoneal injection. Nearly similar result was recorded by [23] where $\mathrm{LD}_{50}$ was $1.14 \times 10^{7} \mathrm{CFU}$. This minor difference is probably due to difference in fish weight (40-45 g). Meanwhile, [24] found that the $\mathrm{LD}_{50}$ of Streptococcus iniae in Oreochromis niloticus was $1 \times 10^{5}$ to $1 \times 10^{6}$. That was almost to same difference in the weight of fish used (15-25 g).

The antimicrobial sensitivity tests indicated sensitivity of the tested Streptococcus iniae strain to florfenicol. That was described by [24-26]. They recorded high sensitivity of Streptococcus iniae to florfenicol. Our results showed that the 
MIC of florfenicol against tested Streptococcus iniae strain was $8 \mu \mathrm{g} / \mathrm{ml}$. That was the same MIC of florfenicol as described by [26] while it was slightly higher than that recorded by [24] which was $2 \mu \mathrm{g} / \mathrm{ml}$. This difference could be attributed to the difference in the tested isolates. Results revealed a high sensitivity of tested Streptococcus iniae strain to norfloxacin. That was in agreement with results described by $[23,27,28]$. They recorded the sensitivity of Streptococcus iniae isolated from fish to norfloxacin. MIC of norfloxacin against tested Streptococcus iniae strain was $0.25 \mu \mathrm{g} / \mathrm{ml}$ which was matching MIC against most aquatic pathogenic bacteria $(0.244 \mu \mathrm{g} / \mathrm{ml})$ as described by [29]. The agar disc diffusion and broth micro dilution tests also, revealed sensitivity of tested Streptococcus iniae strain to oxytetracycline. That was in agreement with results described by [23,30-32]. They recorded the sensitivity of Streptococcus iniae isolated from diseased fish to oxytetracycline. MIC of oxytetracycline against tested Streptococcus iniae strain was $2 \mu \mathrm{g} / \mathrm{ml}$. That was higher than that recorded by [33] as they found MIC of oxytetracycline against Streptococcus iniae to be $0.5 \mu \mathrm{g} / \mathrm{ml}$. This variation may be due to the difference in the tested isolates.

It was clear that using florfenicol, norfloxacin and oxytetracycline at a dosage level of 50,100 and $100 \mathrm{mg} / \mathrm{kg}$ body weight daily by oral gavage for seven successive days respectively was effective in termination of experimental Streptococcus iniae infection in Oreochromis niloticus. There was not any recorded mortalities in infected florfenicol and norfloxacin treated groups and the survival rate was $100 \%$. It was $80 \%$ in oxytetracycline treated group which was greatly decreased than that of infected non treated group as its survival rate was $40 \%$. This greater increase in survival rate and absence or decreased mortalities resulted mainly by inhibition or destruction of the causative agent under the antibacterial effect of used antibiotics. This result was in agreement with that described by $[8,24,34]$ who recorded a decreased mortality of Oreochromis niloticus and Oreochromis aureus experimentally infected with Streptococcus iniae and treated with florfenicol. This result was also, in agreement with that described by [35-37] as they recorded decreased mortality of flounder, carp and grass carp infected with bacterial fish pathogens and treated with norfloxacin. In keeping with our results [33] recorded the efficacy of oxytetracycline in controlling Streptococcus iniae infection in blue tilapia Tilapia aurea as the group received oxytetracycline at a dose of $100 \mathrm{mg} /$ $\mathrm{kg}$ body weight for 14 days which showed a great increase in survivals which reached $98 \%$ in comparison with infected non treated group which showed a $7 \%$ survival rate.

Regarding the liver and kidney functions (AST, ALT, creatinine and uric acid) there was a significant decrease in AST, ALT, creatinine and uric acid in infected florfenicol or norfloxacin treated groups in comparison with infected non treated group. That indicated the efficacy of both drugs in termination of infection and protection of hepatopancreas and posterior kidney from destructive effect caused by the causative agent and its toxins (streptolysin $S$ ). In infected oxytetracycline treated group there was non-significant decrease in AST, ALT and creatinine from infected non treated group pointing to the presence of some adverse effect on both hepatopancreas and posterior kidney induced by oxytetracycline. In the same manner [38] recorded an increased AST, ALT, creatinine and uric acid of healthy nurse sharks Ginglymostoma cirratum inoculated with oxytetracycline at a dose level of $25 \mathrm{mg} / \mathrm{kg}$ body weight.

In accordance with biochemical results of liver functions the histopathological examination of hepatopancreas of infected florfenicol or norfloxacin treated groups indicated the presence of mild hepatic cell vacuolation with absence of inflammatory reaction. Hepatic cell vacuolation could be due to the response to toxins produced by the causative agent. Meanwhile, the absence of inflammatory reaction was probably due to destruction of the invading organism under the antibacterial effect of both drugs. The histopathological examination of hepatopancreas in infected Oxytetracycline treated group indicated the presence of moderate to severe hepatic cell vacuolation with absence of inflammatory reaction. Hepatic cell vacuolation could occur as a response to both effects of exotoxins produced by the causative agent and oxytetracycline. Meanwhile, the absence of any inflammatory reaction was mainly due to destruction of invading organism under the bacteriostatic effect of oxytetracycline. In agreement with our results, [39] recorded fatty changes and vacuolations in the hepatocytes of healthy Oreochromis niloticus treated with oxytetracycline at a dose of $100 \mathrm{mg} / \mathrm{kg}$ ration for 12 weeks.

Concomitantly with results of serum biochemical determination of creatinine and uric acid, the histopathological examination of posterior kidney tissue of infected florfenicol or norfloxacin treated groups indicated the presence of normal kidney tissue architecture, normal convoluted tubules normal glomeruli and Bowman's space with absence of inflammatory reactions or congestion. Absence of inflammatory reaction and degenerative changes was probably due to absence of destructive effect of invading organism under antibacterial effect of both drugs. The histopathological examination of posterior kidney tissue of infected oxytetracycline treated group indicated the presence of degeneration and detachment of tubular epithelium of some renal tubules, increased Bowman's space and degeneration of some glomeruli together with absence of inflammatory reaction. Degenerative changes present could be due to both effects of exotoxins released from Streptococcus iniae and oxytetracycline on posterior kidney tissue. Meanwhile, the absence of inflammatory reaction is mainly due to the fading of the destructive effect of the invading organism under the bacteriostatic effect of oxytetracycline. Confirming to our results [39] recorded the presence of degenerative changes of posterior kidney tissue with periglomerular lymphocytic aggregation in healthy treated Oreochromis niloticus treated 
with oxytetracycline. [40] also, recorded the presence of diffuse cytoplasmic vacuolization of the renal duct epithelium in kidney of Cyprinus carpio administrated medicated feed containing oxytetracycline at a dose level of $15 \mathrm{mg} / \mathrm{kg}$ body weight.

\section{Conclusion}

It could be concluded that florfenicol and norfloxacin can be considered an effective treatment for control of susceptible Streptococcus iniae infection in Oreochromis niloticus at a dose level of 50 and $100 \mathrm{mg} / \mathrm{kg}$ body weight respectively for seven successive days by oral route without any adverse effect on treated fish. With vigilance, oxytetracycline can be used in treatment and control of susceptible Streptococcus iniae infection in Oreochromis niloticus at a dose level of $100 \mathrm{mg} / \mathrm{kg}$ body weight for seven successive days by oral route considering its adverse effects on hepatopancreas and posterior kidney tissue.

\section{References}

1. William L Shelton, Thomas J Popma (2006) Biology: Tilapia biology, culture and nutrition. Food Production Press, USA

2. FAO (2012) The state of world fisheries and aquaculture. Italy.

3. Bercovier H, Ghittino C, Eldar A (1997) Immunization with bacterial antigens: infections with streptococci and related organisms. Dev Biol Stand 90: 153-160.

4. Mohammad Noor Amal Azmai, Mohd Zamri Saad (2011) Streptococcosis in Tilapia (Oreochromis niloticus): A Review. Pertanika J Trop Agric Sci 34(2): 195-206.

5. Berridge BR, Fuller JD, de Azavedo J, Low DE, Bercovier H, et al. (1998) Development of Specific Nested Oligonucleotide PCR Primers for the Streptococcus iniae 16S-23S Ribosomal DNA Intergenic Spacer. J Clin Microbiol 36(9): 2778-2781.

6. Fuller JD, Camus AC, Duncan CL, Nizet V, Bast DJ, et al. (2002) Identification of a Streptolysin S-Associated Gene Cluster and Its Role in the Pathogenesis of Streptococcus iniae disease. Infect Immun 70(10): 5730-5739.

7. Chun-Yao Chen, Gregory A Wooster, Paul R Bowser (2004) Comparative blood chemistry and histopathology of tilapia infected with Vibrio vulnificus or Streptococcus iniae or exposed to carbon tetrachloride, gentamicin or copper sulfate. Aquaculture 239(1-4): 421-443.

8. Mohamed OT Badr, Mohamed A Hashem, Shefaa Ali Elmandraw (2012) Clinicopathological studies on some antibiotics used in Nile tilapia infected with Streptococcus iniae. Journal of American Science 8(12): pp. 1057-1070.

9. Roy PE Yanong (2013) Use of Antibiotics in Ornamental Fish Aquaculture. UF/IFAS Extension, USA.

10. Melba G Bondad-Reantaso, J Richard Arthur, Rohana P Subasinghe (2012) Improving biosecurity through prudent and responsible use of veterinary medicines in aquatic food production. FAO, Italy, pp. 207.

11. Eurell TE, Lewis DH, Grumbles LC (1978) Comparison of selected diagnostic tests for detection of motile aeromonas septicemia in fish. Am J Vet Res 39(8): 1384-1386.

12. Shawn D Coyle, Robert M Durborow, James H Tidwell (2004) Anesthetics in Aquaculture. SRAC Publication No. 3900.

13. NCCLS, National Committee for Clinical Laboratory Standard (1994) Performance standards for antimicrobial disc and dilution susceptibility tests for bacteria isolated from animals, proposes standard. Publication M 31-p NCCAS Document p. 14-20.
14. Ron A Miller (2007) Development of standardized antimicrobial susceptibility testing methods and Aeromonas salmonicida epidemiologic cutoff values for antimicrobial agents used in aquaculture. USA.

15. Plumb JA, Bowser PR (1982) A laboratory manual of Microbial fish diseases. Auburn Univ, p. 77.

16. Dilok Wongsathein (2012) Factors affecting experimental Streptococcus agalactiae infection in tilapia (Oreochromis niloticus). University of Stirling, UK.

17. Lucky Z (1977) Methods for the diagnosis of fish diseases. Amerind publishing Co, PTV. LTD, INDIA and USA, pp. 131.

18. Reitman S, Frankel S (1957) A colorimetric method for the determination of serum glutamic oxalactic and glutamic pyruvic transaminases. Am J Clin Pathol 28(1): 56-63.

19. Haickel R, Godsden RH, Sherwin JE, Spare PD, Tarallo P, et al. (1983) Assay of creatinine in serum with use of fuller's Earth to remove interference. In: Cooper GR (Eds.), Selected Methods of clinical chemistry, American Association for clinical chemistry, USA, 10: pp. 225-229.

20. Barham D, Trinder P (1972) Enzymatic determination of uric acid. Analyzed, 97: 142-145.

21. Drury AA, Wallington TEA (1980) Carleton's histological Technique. ( $5^{\text {th }}$ edn), Oxford Univ.

22. Snedecor GW, Cochran NG (1989) Statistical Methods ( $8^{\text {th }}$ edn), IOWA, USA.

23. Naraid Suanyuk, Nirut Sukkasame, Nopparat Tanmark, Terutoyo Yoshida, Toshiaki Itami, et al. (2010) Streptococcus iniae infection in cultured Asian sea bass (Lates calcarifer) and red tilapia (Oreochromis sp.) in southern Thailand. Songklanakarin J Sci Technol 32(4): 341348.

24. Gaunt PS, Sun F, Endris R (2004) Efficacy of florfenicol for control of mortality caused by Streptococcus iniae in tilapia. Proceedings of Aquaculture, the World Aquaculture Society, USA, pp. 216.

25. Darwish AM (2007) Laboratory efficacy of florfenicol against Streptococcus iniae infection in sunshine bass. J Aquat Anim Health 19(1): 1-7.

26. Figueiredo HC, Netto LN, Leal CA, Pereira UP, Mian GF (2012) Streptococcus iniae outbreaks in Brazilian Nile tilapia (Oreochromis niloticus L:) farms. Braz J Microbiol 43(2): 576-580.

27. Anna Sierosławska, Cezary J Kowalski, Andrzej K Siwicki, Elżbieta Terech-Majewska, Anna Rymuszka (2007) The in vitro influence of norfloxacin nicotinate on the selected immune cell functions in rainbow trout (Oncorhynchus mykiss). Central European Journal of Immunology 32(2): 92-96.

28. Hich Tran Vi, Quyen Vu Dang Ha, Dung Nguyen Huu, Heidrun Inger Wergeland (2013) Experimental Streptococcus iniae infection in barramundi (Lates calcarifer) cultured in Vietnam. International Journal of Aquatic Science 4(1): 3-12.

29. Su ZX, Xiao H, Chen LH (2011) Antibacterial activity of three antibiotics on three common fish pathogenic bacteria in vitro. Chinese Journal of Preventive Veterinary Medicine 23(6).

30. Ramesh P Perera, Sterling K Johnson, Donald H Lewis (1997) Epizootiological aspects of Streptococcus iniae affecting tilapia in Texas. Aquaculture 152(1-4): 25-33.

31. Najiah Musa, Lee Seong Wei, Nadirah Musa, Ruhil H Hamdan, Lee Kok Leong, et al. (2009) Streptococcosis in red hybrid tilapia (Oreochromis niloticus) commercial farms in Malaysia. Aquaculture Research 40: 630-632.

32. Park YK, Nho SW, Shin GW, Park SB, Jang HB, et al. (2009) Antibiotic susceptibility and resistance of Streptococcus iniae and Streptococcus 
parauberis isolated from olive flounder (Paralichthys olivaceus). Vet Microbiol 136(1-2): 76-81.

33. Ahmed M Darwish, Steven D Rawles, Bill R Griffin (2002) Laboratory Efficacy of Oxytetracycline for the Control of Streptococcus iniae Infection in Blue Tilapia. Journal of Aquatic Animal Health 14(3): 184190.

34. Darwish, Ahmed (2010) Effectiveness of Early Intervention with Florfenicol on a Streptococcus iniae Infection in Blue Tilapia. North American Journal of Aquaculture 72(4): 354-360.

35. Gang-Joon Heo, Jeong-Ho Kim (1996) Efficacy of Norfloxacin for the Control of Edwardsiella tarda Infection in the Flounder Paralichthys olivaceus. Journal of Aquatic Animal Health 8(3): 255-259.

36. Zhang, YB, Zhang ZX, Zheng W, Liu YH (2000) Application of Norfloxacin in treatment of bacterial diseases in fishes. Journal of Daliian Fisheries University 15(2).
37. Weidong Zheng, Haipeng Cao, Xianle Yang (2012) Grass carp (Ctenopharyngodon idellus) infected with multiple strains of Aeromonas hydrophila. African Journal of Microbiology Research 6(21): 4512-4520.

38. James Gelsleichter, Enric Cortes, Charles A Manire, Robert E Hueter, John A Musick (1998) Evaluation of toxicity of oxytetracycline on growth captive nurse sharks Ginglymostoma cirratum. Fishery bulletin 96: 624-627.

39. Rasha M Reda, RE Ibrahim, El-Nobi G Ahmed, ZM El-Bouhy (2013) Effect of oxytetracycline and florfenicolas growth promoters on the health status of cultured Oreochromis niloticus. Egyptian Journal of Aquatic Research 39(4): 241-248.

40. Svobodova, Z.; Sudova, E.; Nepejchalova, L.; Aervinka, S.; Vykusova, B.; Modra, H. and Kola, O. J. (2006): Effects of Oxytetracycline Containing Feed on Pond Ecosystem and Health of Carp (Cyprinus carpio L.). Acta Vet Brno, 75, pp. 571-577.

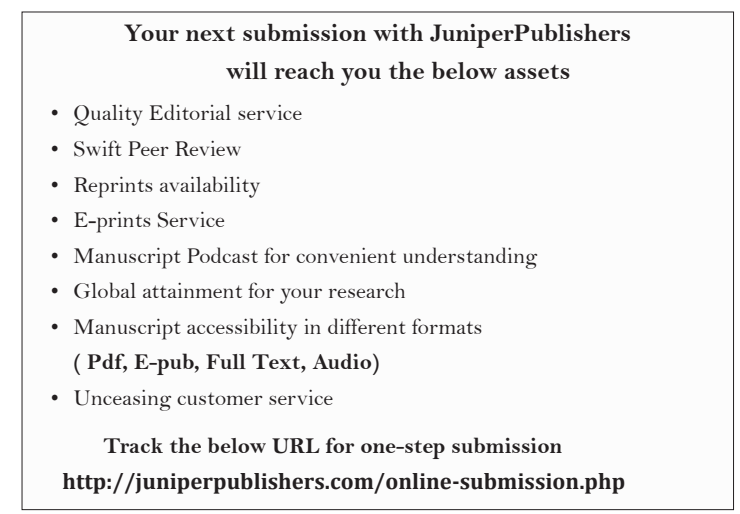

